\title{
研究詥文 $\mathrm{CHC}$ とトリアジン一非水溶液処理鋼板,
}

\section{ステンレス板あるいは鋳鉄板との接着 ${ }^{\dagger}$}

\author{
河野 隆年*·小向 隆志*・佐々木英幸*・瀬川 晃児*
}

\begin{abstract}
要旨 冷間王延鋼(以下，SPCC と略記)，ステンレス鋼(以下，SUS と略記)およびタクタイル鉡鉄(以

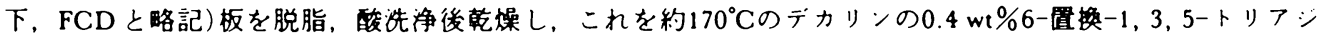

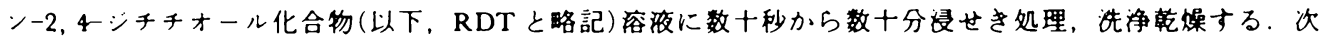
に，この板上でェピクロルヒドリンーェチレンオキンド共重合コム(CHC) 100部，カーボンブラック40部, スプリンター $(\mathrm{R} 300) 3$ 部、酸化亜鉛 5 部および 1, 3, 5-トリアジン-2, 4, 6-トリチオール（以下，Fと略記） 1.77 部の混镧物を9.8 MPa で $160^{\circ} \mathrm{C} 40$ 分間ブレス加硫した。

その結果，RTDがFで骎せき時間 5〜30分の場合，SPCC, SUSおよびFCD板と CHCの接着はく離强

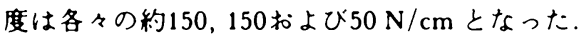

また，6-ジアリル-2.4-ジチオール-1，3，5-トリフジン(以下，DAと略記)あるいは6-ジブチルー2.4-ジチ オール-1,3，5-トリアジン(以下，DB と略記)容夜での浸せき処理によるSPCC 板と CHCとのはく強度 は䄪 $150 \mathrm{~N} / \mathrm{cm}$ であった。
\end{abstract}

\section{1. 緒言}

著者らは前報1において CHC と銅板の接着は， 銅板を脱脂, 酸処理後 RTD の非水溶液で数秒間 浸せき処理後ブレス橋かけすれば可能であること を報告した。

一方，中村，森らは銅以外の金属についても RTDのナトリウム塩水溶液浸せきによる金属処 理で CHC との接着を検討し2)，接着が可能とし ているが，詳細な報告はない，しかし， CHC と SPCC 板，SUS 板およびFCD 板との接着技術も 工業製造には必須の技術と考之，これらの金 属材料表面上にも銅板之同様，RTD-非水溶液浸 せき処理により，RTD 金属皮膜の形成が可能 か，また，これらの RTD 皮膜形成材料と CHC とがプレス加硫により接着が可能か検討した。

その結果，SPCC，SUSおよびFCD表面上に 数十秒から数十分の浸せき時間でRTD 金属皮膜 の形成が可能であること，また，これらの RTD 金属皮膜形成した金属板と CHC の接着はブレス

†本報を「トリフジン化合物を用いるコムと金属の 接着 (第 2 報)」とする.

*岩手県工莱試倹場( $\bar{T} 020-02$ 岩手県盛岡市津志田 26)
加硫により可能であり，SPCCおよびSUSでの 接着は CHCが㠜集破壊するはく漓强度的 $150 \mathrm{~N} /$ $\mathrm{cm}$ を FCD では約 $50 \mathrm{~N} / \mathrm{cm}$ を得ることができた ので，接着機楧と合わせて報告する。

\section{2. 測 定 装 置}

F, DA および DA 皮膜厚測定，皮膜確認，は く離強度試呀扣よび皮膜解析は前報1)之同じ機器 を使用した。

\section{3. 実監}

\section{1 トリアジンチオール化合物および容刷}

FおよびDBは市販品をかタノールで再結晶し た。 た，DAは岩手大学森研究室で合成したも の(融点：227 $\mathrm{C} \mathrm{C})$ をそのまま使用した。また、デ カリンは市販 1 級品をそのまま使用した。

\subsection{RTD 皮膜形成}

市販 SPCC および Photo. 1 の FCD (GC200の 平面研削盤て仕上げした)板 $(2 \mathrm{~mm} \times 30 \mathrm{~mm} \times 50$ $\mathrm{mm})$ は, アセトン脱脂, 乾燥後 $70^{\circ} \mathrm{C}$ の $1 \%$ 塩酸溶 液 $(0.1 \% \mathrm{n}-$ オクチルアミン添加)に 1 分間浸せき 後, 水洗净, ×夕人一儿洗浄後真空乾燥器 $\left(40^{\circ} \mathrm{C}\right)$ で乾燥し、試鈋に供した。な，市販 SUS (SUS304) 板 $(2 \mathrm{~mm} \times 30 \mathrm{~mm} \times 50 \mathrm{~mm})$ は70 $0^{\circ} \mathrm{C} 10 \%$ 硫酸溶液に 30 秒間浸せきし，その後，水洗浄， 


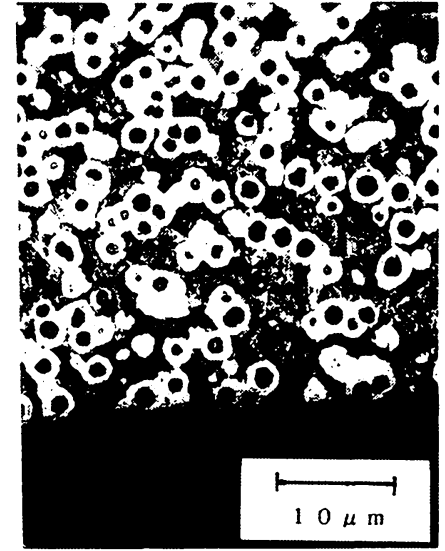

Photo. 1 Microstructure of FCD

Chemical composition; C: $3.69 \%$, Si: $2.90 \%, \mathrm{Mn}$ : $0.22 \%$, P: $0.48 \%$, S: $0.018 \%, \mathrm{Mg}$ : $0.062 \%$

タノール洗浄後真空乾燥器 $\left(40^{\circ} \mathrm{C}\right)$ で乾燥し準備 した。ただし，FCD 板の前処理は，脱脂のみの 試験片も準備した。

次に，この試験片を所定の温度 $\left(140 \sim 180^{\circ} \mathrm{C}\right)$ に擋找，加温したデカリン溶夜 $(\mathrm{F}, \mathrm{DA}$ あるいは DB 添加濃度 0.4 wt \%)に浸せきし，F，DA あるい は DB 皮膜を形成させる. 所定の浸せき時間後， 試験片を取り出し,デカリン中で领却後, アセト ンで洗浄し，乾燥器に入れ乾燥・放冷 L, F, DA あるいは DB 金属皮膜を形成させた金属片を 作成した。

\section{$3.3 \mathrm{CHC}$ の調整と SPCC, SUS あるいは FCD との接着}

CHC の調整方法，プレス橋かけ条件およびは く離強度試験方法は，前報"と同様とした。

\section{4. 結果および考察}

\section{1 浸せき時間と RTD 金属皮膜厚変化}

Fig. 1 およびFig. 2 にあるいは DA（添加濃 度 $0.4 \mathrm{wt} \%$ ，浸せき温度 $\left.140 \sim 180^{\circ} \mathrm{C}\right)$-デカリン溶 液浸せきによるSPCCおよびSUS表面上の RTD 金属皮膜形成量変化を示す。また，Fig. 3 に DB (添加浱度 : $0.4 \mathrm{wt} \%$, 浸せき温度 : $165^{\circ} \mathrm{C}$ ) ーデカリン溶液浸せきによる FCD 表面上の RTD 金属皮膜形成量変化を示す。さらに，Fig. 4 に $\mathrm{F}$ (添加濃度 : $0.4 \mathrm{wt} \%$ ，浸せき温度：160 $190^{\circ} \mathrm{C}$ ) -デカリン溶液浸せきによる FCD 表面上 の RTD 金属皮膜形成量変化を示す.

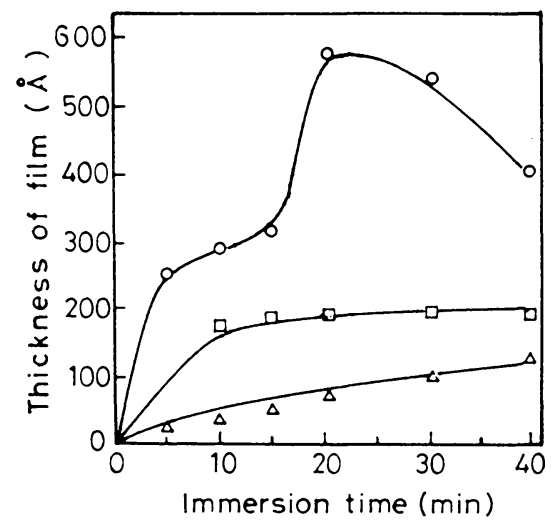

Fig. 1 Effect of immersion temperature and time for the thin films on the SPCC plate treated in $0.4 \mathrm{wt} \%$ $\mathrm{F}$-decalin solution

SPCC: Steel Plate Cold Commercial (JIS)

F: 1, 3, 5-Triazine-2, 4, 6-trithiol

$\triangle: 140^{\circ} \mathrm{C}, \square: 160^{\circ} \mathrm{C}, \bigcirc: 180^{\circ} \mathrm{C}$

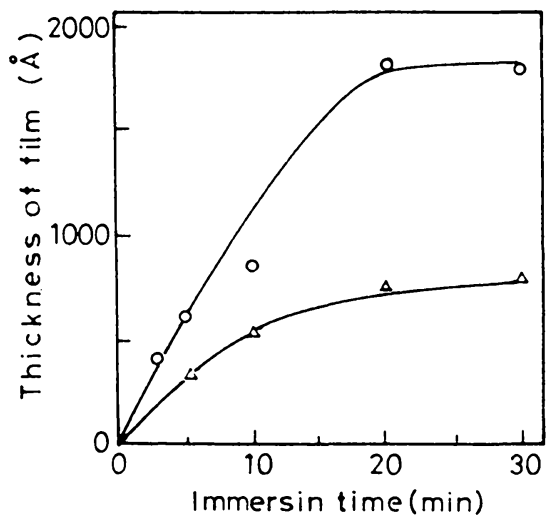

Fig. 2 Effect of immersion temperature and time for the thin films on the SUS (304) plate treated in 0.4 wt $\%$ DA-decalin solution

SUS: Steel Special Use Stainless (JIS)

DA: 6-Diallylamino-1, 3, 5-triazine-2, 4-dithiol $\triangle: 170^{\circ} \mathrm{C}, \square: 180^{\circ} \mathrm{C}$

これらの結果から，RTDナトリウム塩の水溶 液浸せきでは RTD 金属皮膜の形成が困難とされ る3) SPCC, SUS および FCD 板表面にも RTD非水溶液浸せきにより RTD 金属皮膜の形成が可 能であることがわかる。

また，RTD 金属皮膜厚は RTD 濃度が高く， 浸せき時間の長い方が厚くなることがわかる。し 


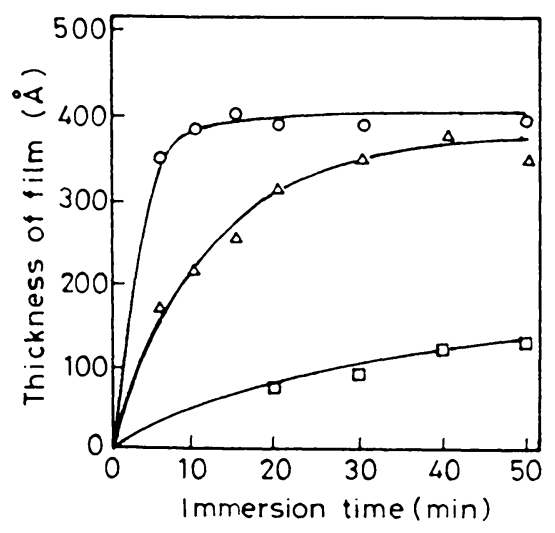

Fig. 3 Effect of immersion time for the thin films on the FCD plate treated in DB-decation solution at $170^{\circ} \mathrm{C}$

FCD: Ferros Casting Ductile

DB: 6-Dibutylamino-1, 3, 5-triazine-2, 4-dithiol Conc. (wt\%) of $\mathrm{DB} ; \square: 0.3, \triangle: 0.6, \square: 0.9$

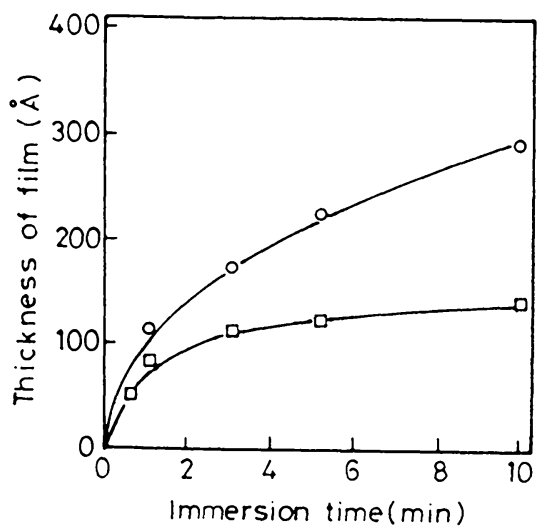

Fig. 4 Effect of immersion time for the thin films on the FCD plate treated in $0.4 \mathrm{wt} \% \mathrm{~F}$-decalin solution at $170^{\circ} \mathrm{C}$

Pretreatment of FCD plate: $\bigcirc: 1 \% \mathrm{HCl}$ soln., non- $\mathrm{HCl}$ soln

かし，銅および銅合金に比べRTD 金属皮膜厚の 形成がかな小さいことがわかり，SPCCのFデカリン溶液浸せきの場合，約 $1 / 50$ となる。

一方，Fig. 1 の結果は，RTD 金属皮膜厚は極 大值を示すよらにも考えられるが，中村らが報 告2)しているよらにRTD 金属皮膜の脱離が起こ っているためとも考えられる。事実，F一トリエ チレングリコール溶液では浸せき時間が長くなる

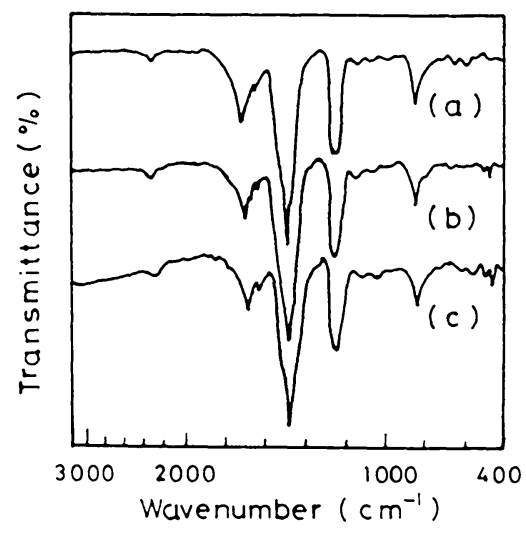

Fig. 5 IR spectra of the SPCC plate surface treated in $0.4 \mathrm{wt} \% \mathrm{~F}$-decalin solution at $170^{\circ} \mathrm{C}$

Immersion time: (a) $300 \mathrm{sec}$, (b) $600 \mathrm{sec}$, (c) $900 \mathrm{sec}$.

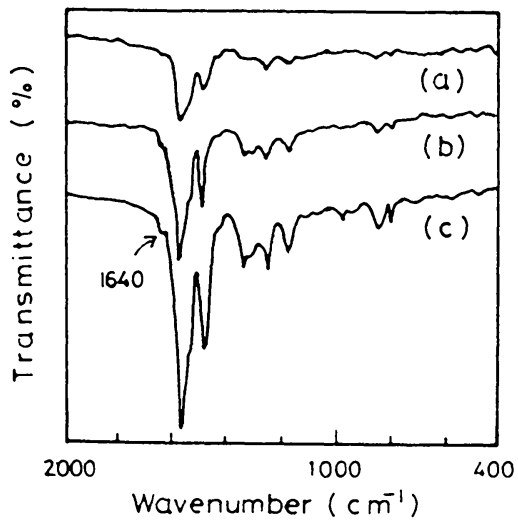

Fig. 6 IR spectra of the SUS plate surface treated in $0.4 \mathrm{wt} \% \mathrm{DA}$-decalin solution at $170^{\circ} \mathrm{C}$

Immersion time: (a) $120 \mathrm{sec}$, (b) $300 \mathrm{sec}$, (c) $1800 \mathrm{sec}$.

\section{と RTD 金属皮膜のはく離が起こる.}

\subsection{RTD 金属皮膜の礁認および皮膜特性}

各金属表面上の RTD 金属皮膜の確認は，高感 度反射法によるIRスペクトルの測定結果から行 った。

Fig. 5 にFーデカリン溶液における浸せき時間 ごとの SPCC 表面のIR スペクトル変化を示す. また，Fig. 6 にDA-デカリン溶液における浸せ き時間ごとのSUS表面のIRスペクトル変化を 示す。さらに，Fig. 7 に-デカリン溶夜に括け 


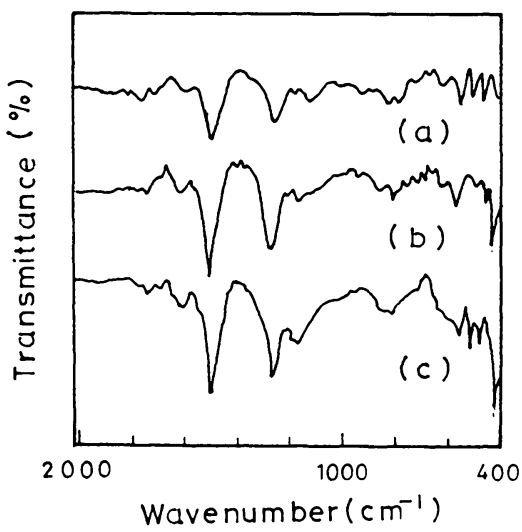

Fig. 7 IR spectra of the FCD plate surface treated in 0.4 wt $\% \mathrm{~F}$-decalin solution Immersion time: (a) $30 \mathrm{sec}$, (b) $180 \mathrm{sec}$, (c) $600 \mathrm{sec}$.

る浸せき時間ごとの鋳鉄表面の IR スペクトル変 化を示す。

これらの結果と先の報告4,5)から，いずれの金 属表面上の IR スペクトルにも $1500 \mathrm{~cm}^{-1}$ K C-N 伸縮振動, $1240 \mathrm{~cm}^{-1}$ に-NH-変角振動, 1150 $\mathrm{cm}^{-1}$ K $>\mathrm{C}=\mathrm{S}$ 伸縮振動および $860 \mathrm{~cm}^{-1}$ に C-S 伸縮振動が認められ，また，Fig. 6 にはアリル基

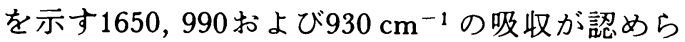
れ， RTD 金属皮膜が形成されていることがわか る.

しかし，浸せき時間が長くなるに従い，IR ス ペクトルのトリアジン環を示す1550付近のピーク に新たに高波数のピークが現れてきており(Fig. $5, \mathrm{C}), \mathrm{RTD}$ 金属皮膜がより鉄元素と配位結合を 強めた表面になっていることが推察できる。また， $\mathrm{FCD}$ 表面では $1150 \mathrm{~cm}^{-1}$ 付近に新たなピークが 現れる (Fig. 7, C)ことから, Fによる鉄塩 (Fig. $13(\mathrm{~d})$ 参照)が形成されていることも推察でさる.

一方，非水溶液浸せきにより形成される RTD 金属皮膜構造についての検討は前報1)に扎いて行 ったが, Fig. 5〜7の IR スペクトルには490, 470 および $460 \mathrm{~cm}^{-1}$ 付近にピークがあり，各 RTD 金属皮膜表面には一-SH 基が含まれていると考え られる。

$4.3 \mathrm{CHC}$ と SPCC, SUS およびFCD 板との 接着はく離強度

Fig. 8，9 にF 又はDA-デカリン溶液浸せき(浸

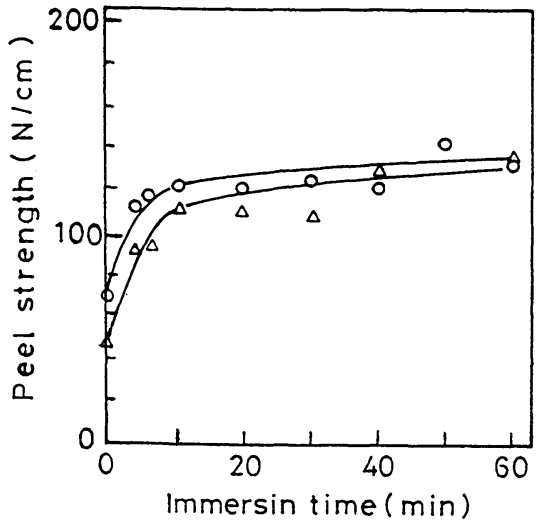

Fig. 8 The peel strength of the crosslinked CHC to SPCC and SUS plate treated in $0.4 \mathrm{wt} \% \mathrm{~F}$-decalin at $170^{\circ} \mathrm{C}$

$\triangle$ : SUS, $\bigcirc$ : SPCC, Valucanization: $160^{\circ} \mathrm{C}-40 \mathrm{~min}$

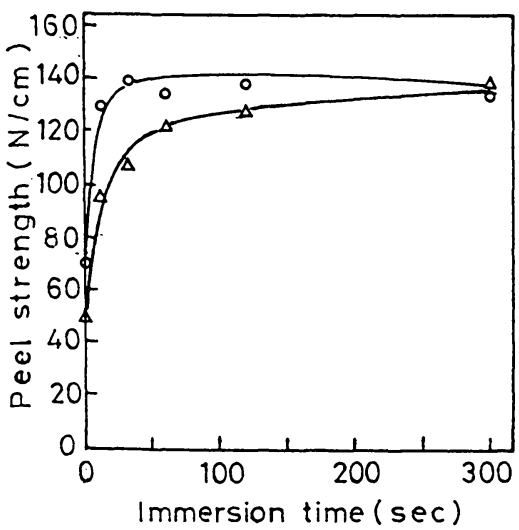

Fig. 9 The peel strength of the crosslinked CHC to SPCC and SUS plate treated in $0.4 \mathrm{wt} \% \mathrm{DA}^{-}$ decalin at $170^{\circ} \mathrm{C}$

$\triangle$ : SPCC, $\bigcirc$ : SUS, Valucanization: $160^{\circ} \mathrm{C}-40 \mathrm{~min}$

せき温度： $170^{\circ} \mathrm{C}$ ) SPCC およびSUS 板と CHC 配合物の接着はく離強度測定結果を示す。また, Fig. 10に DB-デカリン溶液浸せき(浸せき温度： $\left.170^{\circ} \mathrm{C}\right)$ による SPCC 板と CHC 配合物の接着は く離強度測定結果を示す。さらに，Fig. 11 お び12にDBーデカリン溶液浸せき(浸せき温度： $\left.170^{\circ} \mathrm{C}\right)$ および $\mathrm{F}-$ デカリン溶液浸せきによる FCD 板との接着はく離強度測定結果を示す。

これらの結果から RTD 非水溶液浸せきにより SPCC, SUS 怙よび FCD 板と CHC の接着が可能 


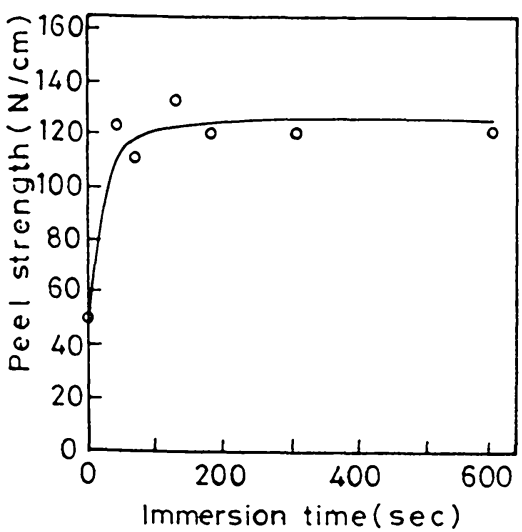

Fig. 10 The peel strength of the crosslinked $\mathrm{CHC}$ to SPCC plate treated in $0.4 \mathrm{wt} \% \mathrm{DB}$-decalin at $170^{\circ} \mathrm{C}$ Valucanization: $160^{\circ} \mathrm{C}-40 \mathrm{~min}$

なことがわかる。また，SPCC およびSUS 板で の最大はく離強度はいずれも約 $150 \mathrm{~N} / \mathrm{cm}$ とな り，凝集破断を示し，実用上問題ないと考えられ る.

また，FCD 板と $\mathrm{CHC}$ との接着では，DB 浱度 の低い溶液処理による RTD 皮膜の方が多少高い はく離強度約 $50 \mathrm{~N} / \mathrm{cm}$ を示し，さらに，塩酸溶 液でFCDを前処理した場合，RTD浸せき処理 が短ければ，多少はく離強度を向上させ，RTD 浸せき処理なしの約 2 倍となるが，実用上問題が 残る.

FCD 板のこの低いはく離強度はFCD 表面の鉄 素地の割合が Photo. 1 に示寸黒鉛の球状化率か ら SPCC 表面の鉄素地の30〜40\%であり，FCD 表面上の RTD 皮膜形成点が少なくなっているた めと考える.このことはFig.10および Fig. 11に 示すSPCC およびFCDのコントロールのはく離 強度結果からも支持できる。

さらに, Fig. 11の結果を Fig. 3 のDB 皮膜形 成状況から検討すると，DB 皮膜厚が $100 \mathrm{~A}$ 以下 の方が膜構造の上で強固と考えることができる.

一方, CHC との接着に必要な RTD 金属皮膜 厚は, Fig. 1〜4の結果から SPCC, SUS および FCD 板とも約 $200 \AA \AA$ 程度であることが，また， この RTD 皮膜を形成する必要浸せき時間は約 $170^{\circ} \mathrm{C} て ゙ 2 〜 30$ 分であることがわかる。

\section{4 接着の機權}

CHC と金属表面の接着機構について，中村ら

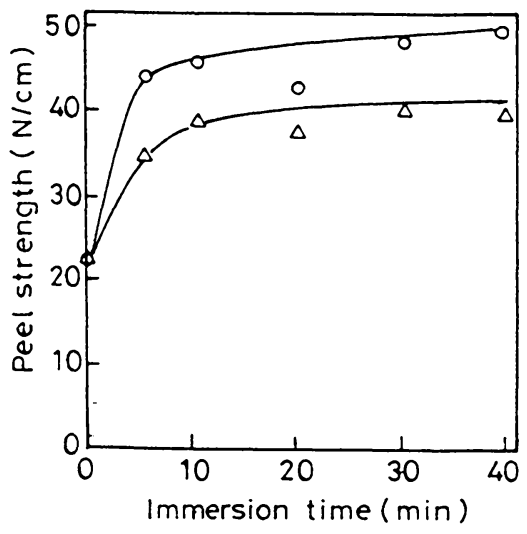

Fig. 11 The peel strength of the crosslinked $\mathrm{CHC}$ to FCD plate treated in $\mathrm{DB}-$ decalin at $170^{\circ} \mathrm{C}$ Conc. $(\%)$ of $\mathrm{BD} / \bigcirc: 0.2, \triangle: 0.4$ Valucanization: $160^{\circ} \mathrm{C}-40 \mathrm{~min}$

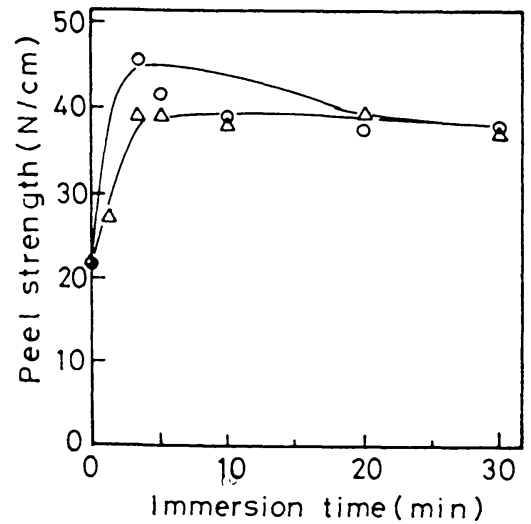

Fig. 12 The peel strength of the crosslinked $\mathrm{CHC}$ to FCD plate treated in $0.4 \mathrm{wt} \% \mathrm{~F}$-decalin at $170^{\circ} \mathrm{C}$ Pretreatment: $\bigcirc: 1 \% \mathrm{HCl}$ soln., $\triangle:$ Non- $\mathrm{HCl}$ soln.,

Valucanization: $160^{\circ} \mathrm{C}-40 \mathrm{~min}$

は CHC (RTD 添加)と銅板の接着を検討し， $\mathrm{CHC}$ 中の一つの-SH 基が銅表面と結合し，他の - $\mathrm{SH}$ 基が CHC と反応するカップリング作用に より銅板と CHC とを結合させるとしている6,7). また，中村らはヒドリンゴム(CHR)とRTDの 架橋機構を示し7， RTDによる CHRの架橋は 脱塩酸反応によることを報告している.

これらの報告から，F-デカリン溶液による $\mathrm{RTD}$ 金属皮膜と $\mathrm{CHC}$ の接着機構は RTD 金属 


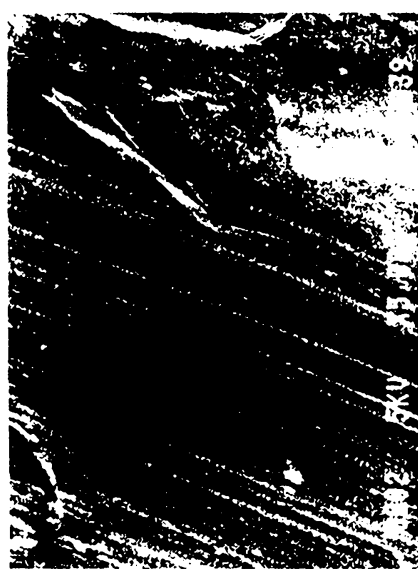

(1)

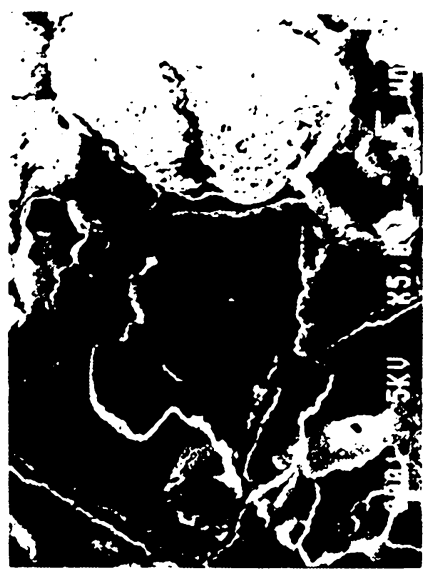

(2)

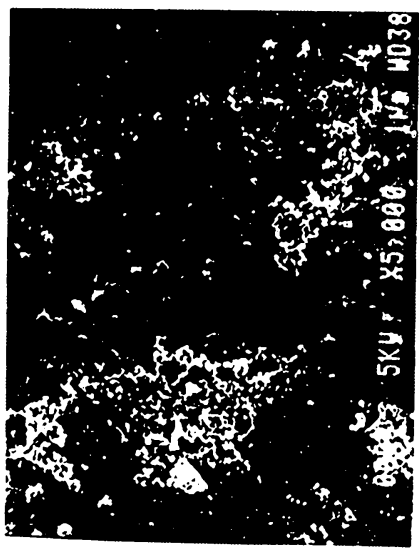

(3)

Photo. 2 SEM of the SPCC surface removed the crosslinked $\mathrm{CHC}^{*}$ to SPCC plate treated in 0.4 wt \% F-decalin solution by ulutorasonic washing with aceton

(1) Blank, (2) Immersion time: $30 \mathrm{sec}$, (3) Immersion time: $300 \mathrm{sec}$

$\mathrm{CHC}^{*}$ : $\mathrm{CHC}(100 \mathrm{phr}$ ), C powder (40 phr), Luburicant (3 phr) and $\mathrm{MgO}$ ( $5 \mathrm{phr}$ )

皮膜が-SH 基に富んでいることから，脱塩酸反 応機構によると考えられるが，RTD金属皮膜と $\mathrm{CHC}$ との間でどのよ5な反応が起きるのかその 機粠について検討した。

すなわち，RTD金属皮膜の厚さの異なる SPCC 板とFを添加しない.CHCをブレス加硫 $\left(160^{\circ} \mathrm{C}, 40\right.$ 分）した後，末架橋の CHCをア七ト ン中で超音波洗浄で浴解除去し，SPCC 表面状態 の観察およびIR スベクトルを測定した。

その結果，表面写真 2 から明らかなよ5に， RTD 金属皮膜は CHC と反応し，CHC 架橋物を 作るが，RTD金属皮膜のない場合は，CHC架 橋物ははとんと作らない。しかし，上述のはく踓 强度試絤結果から，はく離强度の小さいRTD 金 属皮膜厚が約 $200 \dot{\mathrm{A}}$ の場合は，CHC 架橋物が塊 状あるいは硬いゴム皮膜状で付着し，一方，はく 離强度の大きいRTD 金属皮膜が的400 ̊ では， $\mathrm{CHC}$ 架橋物は耀粒状で付着することがわかる。

またこの付着物は後述するIRスペクトル結 果から， RTD 金属皮膜中の-SH 基と CHC 中の 塩素とによる脱塩酸反応による架橋物と考える。 さらに，RTD 金属皮膜厚の違いにより付着量 付着状況の異なるのは，前報”で検討したよらに RTD 金属皮膜形成初期は-SH 基に富んだ表面を 形成し，皮膜厚が厚くなると-S·M(M: Metal)に 富んた表面となるため，膜厚が薄い場合は反応点

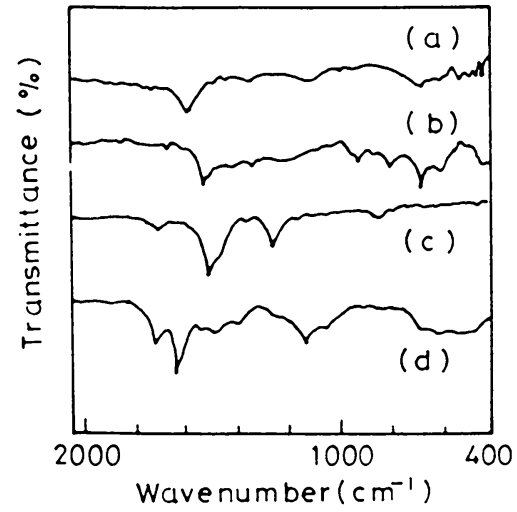

Fig. 13 IR soectra of the SPCC plate surface and $\mathrm{N}_{1}-$ Fe (I) Salt
(a) Surface: (2) in Photo. 1
(b) Surface: (3) in Photo. 1
(c) Treted in $0.4 \mathrm{wt} \% \mathrm{~F}$-decalin at $170^{\circ} \mathrm{C}$
(d) $N_{1}-\mathrm{Fe}$ (I) Salt by $N_{1}$ and iron nitrate in aqueous solution

が多く膜状に，膜厚が厚い場合は，反応点が少な くなり，点状に CHC 架橋物が接着したと考える。

しかし，4.3のはく離強度試殹結果からは浸せ き時間の長い5 分の方がはく襍强度が高い。これ はRTD 金属皮膜の薄い場合，皮膜は多くの-SH 基を含むため，界面は架橋が進んた硬くもろい性 
状になるが，ある程度の皮膜厚さ以上では，-SH 基は適度の含有量となり，適度に CHC と架橋す るためと，中村らが報告した6よ5に CHC 中の Fの-SH 基が鉄表面の酸化物を還元し，CHC 中 の $\mathrm{F}$ が酸化鉄表面と $\mathrm{CHC}$ を強くカップリングし た結果によると考えられる。

このことは，前報"の RTD 金属皮膜の ESCA 分析結果から，RTD-非水溶液浸せきによる RTD 金属皮膜は，浸せき時間が長くなるに従い 酸素含有量を急に高め, 鉄酸化物が RTD 金属皮 膜中に多く形成されていることを示していること からも理解できる。

一方，Fig. 13に示すIRスペクトルはRTD皮 膜形成したSPCC 表面とF添加のないCHCを 加王プレス後，未架橋のCHCを溶解した SPCC 表面で測定したスべクルであり，SPCC 上の RTD 皮膜の薄い場合には，650 $\mathrm{cm}^{-1}$ 付近 にC-Clの伸縮振動ビークを示し，付着物が CHC の架橋物であることを示している，さらに， RTD 金属皮膜が厚い場合には，トリアジンの骨 格振動を示す $1490 \mathrm{~cm}^{-1}$ 付近のピークがブレス加 熱により，高波数側にンフトしている。このこと は， RTD 金属皮膜はブレス加熱中に鉄イオンと の結合を優先させるため，CHC 中の塩素との反 応点を减少させた結果と考えることができる。

また，FCD 板では接着はく離强度が小さかっ たが，RTD 処理 FCD 表面に扣いて上述と同様 の試跲を行った結果，付着物は非常に少なく，前 述のように FCD 表面上の RTD 皮膜形成点が少 ないことが裏付けられた。

以上の結果から， RTD一非水溶液から成形され る RTD 金属皮膜表面と CHC との接着機構は, $\mathrm{RTD}$ 金属皮膜中の-SH 基と $\mathrm{CHC}$ 中の塩素との 脱塩酸反応に基つくく多くの一次結合点を形成する ためと、CHC 中の F の-SH 基が鉄表面の酸化物 を還元し，CHC と鉄表面をカップリングする機 構により接着すると考える。

\section{5. と め}

F，DAあるいはDB-デカリンの非水溶液浸せ きによる SPCC, SUS あるいはFCD 表面上への RTD 皮膜の形成と, この RTD 皮膜形成した各 種板と CHC との接着について検討した。

その結果，RTD皮膜形成したSPCC, SUS お よび FCD 板と CHC との接着は可能であり，接 着はく離强度はそれぞれ約150，150および50 N/ $\mathrm{cm}$ となった。 また，接着に必要な RTD 金属皮 膜を形成する浸せき時間は約 $170^{\circ} \mathrm{C} て ゙ 5 〜 30$ 分が 適当と考えられた。さらに， $\mathrm{CHC}$ との接着のた めの RTD 金属皮膜厚さは約 $200 \sim 400 \AA$ 程度と 考えられた。

一方，RTD 金属皮膜と CHC との接着機構は $\mathrm{RTD}$ 金属皮膜中の-SH 基と $\mathrm{CHC}$ の塩素との脱 塩酸反応と， CHC 中の $\mathrm{F}$ の-SH 基が金属表面の 酸化物を還元し，金属表面と CHC をカップリン グする反応によるものであると考えられた。

〔附記〕本研究は平成 $2 \sim 3$ 年において岩手県技 術おこし事業として実施した成果の一部であり， 御指導下さいました中村儀郎岩手大学名誉教授。 ならびに森邦夫岩手大学教授に深く感謝致します。

\section{文献}

1）河野隆年, 小向隆志, 佐々木英幸, 瀬川晃児：日 コム協誌，66, 312 (1993)

2) 日特：昭60-4108

3）日許：平成 1 年特許願24521号

4) CHUDY, J. C., DALZIEL, J. A. W.: J. Inorg. Nucl. Chem., 37, 2495 (1975)

5）森 邦夫，斉藤 実，中村轙郎：日化, No. 4. 725 (1987)

6）中村儀郎，森 邦夫，兼田正敏：日化，No. 10 . 1620 (1976)

7）中村儀郎，森邦夫，岡作次郎：日コム協誌，46, 779 (1973) 


\section{ADHESION OF CHC RUBBER TO STEEL, STAINLESS STEEL AND CAST IRON PLATES TREATED IN TRIAZINE-NON AQUEOUS SOLUTION}

\section{Takatoshi KOUNO, Takasi KOMUKAI, Hidoyuki SASAKI, Koji SEGAWA (Industrial Resurch Institute of Iwate Profectural Government, 26 Tsushida, Morioka-Shi, Iwate Profecture)}

Adhesion of epichlorohydrin-ethylene oxide rubber to steel, stainless steel and cast iron plates treated in triazin-nonaqueous solution was investigated.

As a triazin compound, 6-Substituted-1, 3,5-triazine-2, 4-dithiol (RTD) was used. $60 \mathrm{~min}$.

Each test plates were immersed in RTD-organic solutions at $140 \sim 180^{\circ} \mathrm{C}$ for $30 \mathrm{sec}$.

SPCC, SUS (304) and FCD were used as test plates, and decalin, benzylacohol and triethyleneglycohol were used as organic solvents.

The thin RTD films of about $50 \sim 600 \mathrm{~A}$ in thickness were formed on test plates when test plates were immersed in RTD-organic solutions,

The treated each plates were overlaid with the blending sheet (CHC 100, C 40, Lublicant 3 , Trithiocyanuric acid (F) $1.77, \mathrm{ZnO} 5 \mathrm{phr}$.) and cures at $160^{\circ} \mathrm{C}$ for $40 \mathrm{~min}$. under $100 \mathrm{kgf} / \mathrm{cm}$.

As a results, the peel strength of adhesion gave $15 \mathrm{kgf} / \mathrm{cm}$ with braking rubber (control: about $6 \mathrm{kgf} / \mathrm{cm}$ ) on the SPCC and SUS plates (immersion time: $5 \mathrm{~min}$.), but the peel strength of adhesion on FCD plate was $5 \mathrm{kgf} / \mathrm{cm}$ (contol: $2 \mathrm{kgf} / \mathrm{cm}$ ).

(Received Seplember 22, 1992) 